\title{
DEVELOPING A WAY TO EXPAND THE RANGE AND IMPROVE THE ACCURACY USING ULTRASONIC SHADOW MEASUREMENT METHOD TO CONTROL THE WIDTH OF THE TAPE IN THE AIR
}

\author{
O. Rishan, O. Tikhonov \\ National University of Food Technologies
}

\begin{tabular}{l} 
Key words: \\
Ultrasonic shadow \\
method \\
Isolation of acoustic zones \\
Measurement error \\
Sampling \\
\hline
\end{tabular}

Article history:

Received 10.05.2018

Received in revised form

28.05.2018

Accepted 14.06.2018

Corresponding author:

O. Rishan

E-mail:

rishan.aleksandr@

gmail.com

\begin{abstract}
The paper presents the results of the development and research of the method of expanding the range and improvement the accuracy of measurements in the implementation of the ultrasonic shadow method in the device for controlling the width of the ribbon semi-finished products in the air. The peculiarity of the use of the shadow method in the air is not the isolation of the acoustic zones of the primary measuring transducers of the width of the device (PMTW) of the device from the environment and, consequently, the influence of this medium on the measurement zones, which manifests itself in the change in the intensity of ultrasonic vibrations on the measuring receiversat when there is a constant bandwidth (the effect of the acoustic phenomen called "feding") and, accordingly, changing the output signals of the receivers and the occurrence of an additional random measurement error.
\end{abstract}

For it sreduction and expansion of the range ofmeasurements, a method of compensating the phenomenon of acoustic "feding" was developed based on the formation of a distributed on the length of the measuring receiver discrete zone with a given sampling step, where there is a compensation of the influence of perturbations, determination of the position of the projection of the edge of the controlled by width bandwidth in the discrete zone and areas of direct perturbation compensation are created at the sampling step, which is closest to the edge of the tape, but it isn't overlapped by it.

The method is implemented in the PMTW of the device with the help of additional correction receivers that are situated in the same plane near the measuring receiver and are distributed along its length, and the determination of an additional correction receiver that isn't blocked by the edge of the tape and is closest to its edge, and its signal is entered into the chain of the negative feedback of the voltage supply control of the package of radiators, so that this signal is maintained unchanged and equal to the given.

DOI: $10.24263 / 2225-2924-2018-24-3-5$ 


\title{
РОЗРОБКА СПОСОБУ РОЗШИРЕННЯ ДІАПАЗОНУ I ПІДВИЩЕННЯ ТОЧНОСТІ ВИМІРЮВАНЬ ПРИ УЛЬТРАЗВУКОВОМУ ТІНЬОВОМУ МЕТОДІ КОНТРОЛЮ ШИРИНИ СТРІЧКИ В ПОВІТРІ
}

\author{
О.Й. Рішан, О.Ю. Тихонов \\ Національний університет харчових технологій
}

У статті наведено результати розробки та дослідження способу розширення діапазону і підвищення точності вимірювань при реалізащії ультразвукового тіньового методу в пристрої контролю ширини стрічкових напівфабрикатів у повітрі.

Особливістю використовування тіньового методу в повітрі є неізольованість акустичних зон первинних вимірювальних перетворювачів ширини (ПВПШ) пристрою від навколишнього середовища $і$, відповідно, вплив иъього середовища на зони вимірювання, яке проявляється в зміні інтенсивності ультразвукових коливань на вимірювальних приймачах при постійній ширині стрічки (вплив явища акустичного «федингу») та зміні вихідних сигналів приймачів і виникненні додаткової випадкової похибки вимірювання.

Для ї̈ зменшення і розширення діапазону вимірювань розроблений спосіб компенсачї явища акустичного "федингу», щсо побудований на утворенні розподіленої по довжсині вимірювального приймача дискретної зони із заданим кроком дискретизаиії, в якій відбувається компенсація впливу збурень, визначенні положення проекиії краю контрольованої по ширині стрічки на дискретній зоні й утворені зони безпосередньої компенсації збурень на кроиі дискретизаиії, який є найближчим до краю стрічки, але не перекривається ним.

Спосіб реалізується в ПВПШ пристрою за допомогою додаткових приймачів коригування, які розташовані в одній площині поряд з вимірювальним приймачем і розподілені по його довжині, та визначенні додаткового приймача коригування, який не перекривається краєм стрічки $і$ є найближчим до ї̈ краю, а його сигнал вводиться в ланиюг від'ємного зворотного зв'язку регулювання напруги живлення пакета випромінювачів, завдяки чому цей сигнал підтримується незмінним і рівним заданому.

Ключові слова: ультразвуковий тіньовий метод, ізольованість акустичних зон, похибки вимірювання, дискретизація.

Постановка проблеми. Для вимірювання ширини стрічкових напівфабрикатів у повітрі, які можуть бути або оптично прозорими або легко піддаватись деформуванню, наприклад, листи для пакування виробів у харчовій промисловості тощо, досліджено ультразвуковий тіньовий диференціальний метод [2].

Головною умовою реалізації такого методу є необхідність великої різниці між акустичними опорами повітря та напівфабрикату. Ця умова виконується через різницю між акустичними опорами повітря та пакувального листа (відрізняються майже на три порядки) і дає можливість отримати чітку тінь від краю пакувального листа на приймачі [3]. 
Ще однією умовою реалізації такого тіньового методу є створення у повітрі рівнорозподіленого за інтенсивністю ультразвукового променя на певній довжині, який перекриває край пакувального листа. Для ії вирішення використана залежність для тиску $P_{U}$ на відстані $H$, яку утворює лінійна група прямокутних ультразвукових випромінювачів, що знаходиться у жорсткому екрані з випромінюванням у півпростір по нормалі до їх поверхні [1] і яка після перетворення може бути записана у такому вигляді:

$$
P_{\amalg}=\frac{\rho C \cdot m \cdot Q}{2 \lambda H}=P_{\text {Ош }} \frac{S_{\mathrm{C}}}{2 \lambda H}=P_{\text {ОШ }} \frac{m \cdot L_{\amalg О} \cdot L_{\Pi}}{2 \lambda H}=P_{\text {ОШ }} \frac{L_{\Pi}}{2 \lambda H} L_{\amalg},
$$

де $\rho C$ - акустичний опір середовища; $\lambda=C / F_{H}$ - довжина ультразвукової хвилі частотою $F_{H} ; m$ - кількість випромінювачів, які утворюють лінійну групу; $P_{\text {Ош }}$ - тиск, який розвиває у своєї поверхні один випромінювач в групі; $Q=S \cdot V$ - об'ємна швидкість джерела ультразвукових коливань, що характеризує здатність випромінювача до утворення акустичного поля; $S$ площина одного випромінювача в групі; $S_{\mathrm{C}}=m \cdot S$ - загальна площина випромінювачів, які утворюють лінійну групу; $V=P_{\text {ош }} / \rho C-$ коливальна швидкість на поверхні одного випромінювача в групі; $L_{\text {шо }}$ - розмір одиночного випромінювача в напрямку зміщення краю стрічки; $L_{\amalg}$ - розмір пакета випромінювачів у напрямку зміщення краю стрічки: $L_{\Pi}$ - розмір одиночного випромінювача в напрямку руху стрічки, що контролюється по ширині; а $L_{\text {шо }} \cdot m \cdot L_{\Pi}=L_{Ш} \cdot L_{\Pi}=S_{\mathrm{C}} ; \mathrm{C}$ - швидкість розповсюдження звуку у повітрі.

Аналіз конструктивного виконання ПВПШ за залежністю (1) показує на доцільність використовування в ньому також прямокутного вимірювального приймача, розподіленого по довжині перекриття ультразвукового променя краєм стрічки. Останнє дає змогу, при використовуванні багатообмоткового вихідного трансформатора живлення випромінювача, зміною напруги живлення окремого випромінювача впливати на інтенсивність розподіленого по дожині загального ультразвукового променя, чим досягається за необхідності лінеаризація вихідного аналогового сигналу ПВПШ [4-6]. Одночасно залежність (1) дає змогу визначити також амплітуду напруги $U_{\text {ш }}$ на виході приймача, що вимірює цей тиск на відстані $H$ від поверхні випромінювача 3 урахуванням величини перекриття $X$ його ультразвукового променя:

$$
U_{Ш}=K_{\text {Пш }} P_{\text {Ош }} \frac{S_{\mathrm{C}}}{2 \lambda H}\left(1-\frac{X}{L_{ш}}\right),
$$

де $K_{\text {пш }}=\partial \mathrm{U}_{\text {ш }} / \partial X=-P_{\text {Ош }} S_{\mathrm{C}} / 2 \lambda H-$ чутливість приймача; $X-$ зміщення краю стрічки, що визиває перекриття ультразвукового променя пакета випромінювачів.

Сигнал приймача досягає максимального значення при $X=0$, а мінімального - при повному перекритті параметра $L_{\amalg}$ пакета випромінювачів, тобто при $X=L_{\amalg}$. Таким чином параметр $L_{Ш}$ встановлює діапазон вимірювання положення краю стрічки і повинен визначатися з умови: 


$$
L_{\amalg} \geq 2|X|+2\left|\Delta B_{\amalg}\right|,
$$

де $\pm X-$ можливе відхилення краю стрічки від вихідного положення, що визивається зміною ширини стрічки; $\pm \Delta B_{\amalg}-$ зміщення вісі стрічки відносно вихідного положення при незмінній ії ширині.

Однією з особливостей такої реалізації тіньового методу контролю стрічки в повітрі $\epsilon$ неізольованість обох акустичних зон вимірювання від навколишнього середовища i, відповідно, вплив зміни швидкості повітряних потоків (турбулентність) в акустичних зонах на результати вимірювання, яке проявляється в зміні інтенсивності $I_{X}$ ультразвукових коливань (тиску) на вимірювальних приймачах при постійній ширині стрічки. Це вплив так званого явища акустичного «федингу», який визиває суттєву додаткову складову похибки вимірювання при реалізації тіньового методу - випадкову похибку $\Delta_{L \Phi}$ флуктуації [2].

3 метою зменшення такої похибки досліджено спосіб, при якому зміною інтенсивності випромінених ультразвукових коливань компенсується вплив розглянутого фактора в зоні, яка не використовується безпосередньо при вимірюванні, але яка знаходиться поряд із зоною вимірювання [2]. Спосіб реалізується в ПВПШ за допомогою додаткового приймача коригування. який розташований поряд 3 вимірювальним приймачем і в одній площині 3 ним, але який не перекривається краєм стрічки, і введенням сигналу цього додаткового приймача в ланцюг від'ємного зворотного зв'язку регулювання напруги живлення пакета випромінювачів, завдяки чому цей сигнал підтримується незмінним і рівним заданому.

Але просторове зміщення між зоною безпосередньої компенсації збурень i зоною вимірювання, а також наявність природного градієнта інтенсивності ультразвукових коливань від дії збурення, рівного $\partial I / \partial x$, обмежують ступінь компенсації збурення в зоні вимірювання. Величина варіації некомпенсованої інтенсивності на відстані $\Delta$ х від зони безпосередньої компенсації приблизно дорівнює: $\Delta I_{X}=(\partial I / \partial x) \Delta x$. Окрім цього, при зменшенні ширини стрічки, ступінь компенсації збурення в зоні вимірювання зменшується через віддалення ії країв стрічки від зон безпосередньої компенсації збурень.

Мета статті: розробка способу розширення діапазону та підвищення точності вимірювань положення країв стрічки ультразвуковим тіньовим методом та структурної схеми пристрою, що реалізує цей спосіб.

Викладення основних результатів дослідження. Для зменшення додаткової складової похибки $\Delta_{L \Phi}$ від флуктуації сигналу вимірювального приймача і розширення діапазону вимірювань розроблено спосіб їх компенсації, суть якого в утворенні розподіленої по довжині вимірювального приймача дискретної зони із заданим кроком дискретизації, визначенні положення проекції краю контрольованої по ширині стрічки на дискретній зоні й утворені зони безпосередньої компенсації збурень на кроці дискретизації, який $є$ найближчим до краю стрічки, але не перекривається ним.

Оцінимо характер зміни та значення випадкової похибки флуктуації $\Delta_{L \Phi}$. Враховуючи, що розповсюдження ультразвукових хвиль у середовищі $з$ ви- 
падковими неоднорідностями можна розглядати в наближенні геометричної оптики, то найбільш загальна формула для середнього значення зміни квадрата логарифму амплітуди $\bar{\psi}^{2}$ сигналу на приймачі, яка враховує турбулентність повітряного середовища зони вимірювання, дорівнює [3]:

$$
\sqrt{\bar{\psi}^{2}}=2,3 \frac{A_{\Phi} \cdot L^{3 / 2}}{C \cdot K^{7 / 6} \cdot \lambda^{7 / 6}},
$$

де $A_{\Phi}$ - характеристика турбулентності $\left[\mathrm{m}^{2 / 3} / \mathrm{c}\right] ; k=2 \pi / \lambda-$ хвильове число; $\lambda$ - довжина ультразвукової хвилі $[\mathrm{M}] ; C$ - швидкість розповсюдження ультразвуку $[\mathrm{m} / \mathrm{c}] ; \quad L-$ довжина відкритої частини приймача, на якій проектується край стрічки.

Ця залежність може бути представлена для акустичної зони вимірювання ПВПШ у такому вигляді:

$$
\sqrt{\left[\ln \left(\frac{U}{U_{\text {ОШ }}}\right)\right]^{2}}=\sqrt{\left[\ln \left(1+\frac{\Delta U_{\amalg}}{U_{\text {ОШ }}}\right)\right]^{2}}=A_{\Phi} \cdot L^{3 / 2},
$$

де $U$ - плинне значення амплітуди сигналу на вимірювальному приймачі;

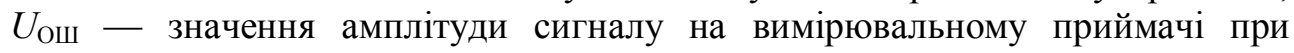
відсутності турбулентності в зоні вимірювання; $L$ - відстань між положенням проекції краю стрічки на вимірювальному приймачі і зоною, де здійснена стабілізація сигналу на приймачі коригування; $\Delta U_{\text {ш }}$ - відхилення сигналу

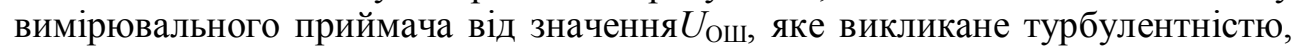
тобто випадкова абсолютна $\Delta L \Phi$ похибка вимірювання.

Враховуючи, що

$$
\sqrt{\overline{\left[\ln \left(1+\frac{\Delta U_{\amalg}}{U_{\text {ОШ }}}\right)\right]^{2}}}=\frac{\sum_{i=1}^{n}\left[\ln \left(1+\frac{\Delta U_{\amalg i}}{U_{\text {ОШ }}}\right)\right]^{2}}{n},
$$

то в межі при $n \rightarrow \infty$ (при великій кількості вимірювань для знаходженні середнього) можемо записати:

$$
\sqrt{\left[\left[\ln \left(1+\frac{\Delta U_{\amalg}}{U_{\text {ОШ }}}\right)\right]^{2}\right.} \cong \sqrt{\left[\ln \left(1+\gamma_{S L \Phi}\right)\right]^{2}}=A_{\Phi} L^{3 / 2},
$$

де $\gamma_{S L \Phi}$ - додаткова випадкова відносна похибка від флуктуації сигналу на вимірювальному приймачі, яка після перетворення залежності (7) дорівнює:

$$
\gamma_{S L \Phi}=e^{A_{\Phi} \cdot L^{3 / 2}}-1
$$

Залежність (8) показує, що додаткова випадкова похибка флуктуації зростає по експоненті в міру відкриття вимірювального приймача краєм контрольованої по ширині стрічки.

Спосіб зменшення такої випадкової похибки флуктуації з одночасним розширенням діапазону вимірювання реалізовано в ПВПШ пристрою контролю ширини стрічки з розподіленою по довжині вимірювального приймача 
дискретною зоною компенсації впливу збурень, структурна схема якого приведена на рис. 1.

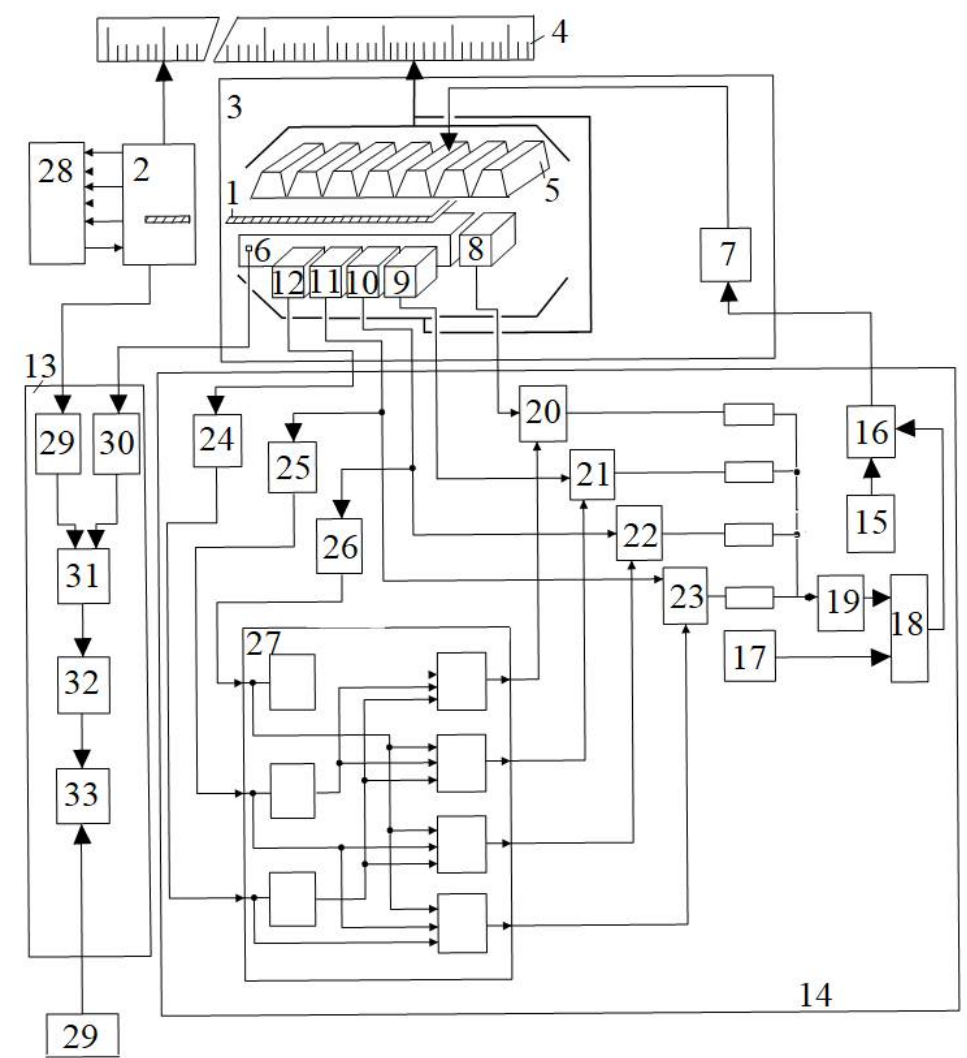

Рис. 1. Структурна схема пристрою контролю ширини стрічки з розподіленою по довжині вимірювального приймача дискретною зоною компенсації впливу збурень

Спосіб реалізується за допомогою $n$ додаткових приймачів коригування, які розташовані в одній площині поряд з вимірювальним приймачем і розподілені послідовно по його довжині, при чому $n$-й додатковий приймач ніколи не перекривається краєм стрічки. Стабілізація сигналу на цьому додатковому приймачі забезпечує компенсацію впливу збурень у зоні вимірювального приймача 3 необхідним ступенем компенсації по залежності (8) тільки над частиною вимірювального приймача, по довжині, рівній довжині додаткового приймача.

Для такого варіанта виконання ПВПШ (рис.1) із залежності (6) отримана умова вибору довжини додаткового приймача, яка визначається залежністю:

$$
L_{\text {д }} \leq \sqrt{\left\{\frac{\ln \left(1+\Delta_{\text {фд }}\right)}{A_{\phi}}\right\}^{3}},
$$

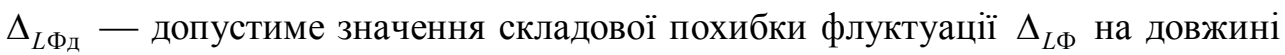
вимірювального приймача довжиною $L_{\text {д }}$. 
У міру зменшення ширини стрічки або ііі зміщенні по вісі, які викликають подальше відкриття вимірювального приймача, відбувається послідовно повне відкриття розподілених по його довжині таких додаткових приймачів. Зона безпосередньої компенсації збурень відслідковує зміщення краю стрічки і підтримується на відстані, яка визначається залежністю (9). При цьому на першому кроці дискретизації визначається за мінімальним сигналом додаткового приймача $n-2 n$-1-й додатковий приймач, який не перекривається краєм стрічки є найближчим до краю стрічки. Зона безпосередньої компенсації збурень переноситься на $n-1$-й додатковий приймач тощо.

Пристрій складається 3 двох акустичних вузлів 2 і 3 ПВПШ, які утворюють дві зони вимірювання, кожна $з$ яких являє жорстко скріплені і направлені назустріч пакета ультразвукових випромінювачів 5 і приймачів 6.

Вузли вміщують також ультразвукові генератори 7, кожен 3 яких оснащений багатообмотковим вихідним трансформатором (на рис. 1 не показано). Кожна з обмоток трансформатора живить окремий п'єзоелемент пакета випромінювачів 5 ПВПШ.

У зоні вимірювання між пакетом випромінювачів 5 і вимірювальним приймачем 6 ПВПШ утворюється рівномірно розподілений за інтенсивністю ультразвуковий промінь, який перекривається краєм стрічки 1, а аналоговий сигнал на виході приймача 6 пропорційний величині цього перекриття за залежністю (2).

За необхідності сигнал приймача 6 лінеаризується зміною напруги живлення окремого випромінювача у пакеті 5 за допомогою додаткового змінного опору, який розміщено в ланцюгу його збудження (на рис. 1 не показано). При цьому стрічка $\mathbf{1}$, що контролюється по ширині, знаходиться між пакетом випромінювачів 5 і приймачами 6 кожної зони, а їі лівий і правий краї перекривають ультразвукові промені між ними.

Пристрій реалізує диференціальний метод вимірювання, тобто контролює тільки відхилення ширини стрічки від заданого номінального значення, яке виставляється на кронштейн-лінійці 4 пропорційним зміщенням акустичних вузлів у протилежних напрямах.

На рис.1 розкрито тільки один акустичний вузол 3 ПВПШ для контролю правого краю контрольованої по ширині стрічки 1. Акустичний вузол 2 контролю другого краю стрічки ідентичний наведеному. Акустичний вузол 3 вміщує також додаткові приймачі коригування 8-12, які розташовані в безпосередній близькості і в одній площині 3 основним вимірювальним приймачем 6, причому додатковий приймач 8 (на відміну від приймачів 912) краєм стрічки 1 не перекривається.

У склад пристрою входить також блок 14 керування 3 генератором 15, частота релаксації якого відповідає резонансній частоті випромінювачів 5 i приймачів 6, 8-12, та схема 16 автоматичного регулювання підсилення (АРП), яка задає рівень вхідного сигналу генератору 7, чим задається безпосередньо напруга збудження пакета випромінювачів $\mathbf{5 .}$

Крім цього, пристрій вміщує електронний блок 13, до двох входів якого надходять сигнали по залежностям (2) від вимірювальних приймачів 6 обох вузлів 2 та 3. Схеми 29 та 30 блоку 13 здійснюють підсилення та детекту- 
вання аналогових сигналів вимірювальних приймачів 6, а схема суматора 31 здійснює їхнє алгебраїчне додавання, чим забезпечується незалежність результату вимірювання від можливого зміщення вісі стрічки 1 між акустичними вузлами 2 та $\mathbf{3}$ без зміни ії ширини. Цифровий код з аналого-цифрового перетворювача 32, який пропорційний відхиленню ширини стрічки 1 від ії номінального значення, надходить у блок 33, де теж алгебраїчно додається до еталонної ширини, яка вводиться схемою 29. Значення останньої дорівнює номінальному значенню ширини стрічки 1, що виставлене на кронштейн-лінійці 4. Блок 33 одночасно здійснює цифрову індикацію результату вимірювання.

При зменшенні ширини стрічки або іiі зміщенні по вісі між акустичними вузлами 2 та 3, які визивають перекриття ультразвукового променя пакета випромінювачів 5, частина цього променя діє на додатковий приймач коригування $\mathbf{8}$, який знаходиться поза зоною вимірювання і не перекривається краєм стрічки. Додаткові приймачі коригування 9-12 перекриті і сигнал на їх виходах дорівнює нулю. Одночасно дорівнюють логічному нулю сигнали на виходах амплітудних дискримінаторів 24-26, що забезпечує появу логічної одиниці на виході дешифратора 27 і ввімкнення ключового елемента 20. Останній з'єднує вхід підсилювача 19 коригування 3 виходом додаткового приймача 8, чим забезпечується підтримування схемою АРП рівня сигналу приймача 8 незмінним і рівним заданому, установленому від джерела опорної напруги 17.

Стабілізація сигналу на першому додатковому приймачі коригування 8 забезпечує компенсацію впливу збурень у зоні вимірювального приймача 63 необхідним ступенем компенсації тільки над частиною вимірювального приймача по довжині, що дорівнює довжині додаткового приймача $L_{\partial} 9$.

Подальше зменшення ширини стрічки або іiі зміщенні по вісі між акустичними вузлами 2 та 3 спричиняє більше відкриття вимірювального приймача 6 та повне відкриття додаткового приймача коригування 9 і часткове відкриття приймача коригування 10. Амплітудний компаратор 26 налаштовується на мінімальний сигнал приймача 10 і високий потенціал на його виході свідчить про повне відкриття приймача коригування 9 і можливості використовування його як коригувального. При цьому високий потенціал з'являється тільки на виході дешифратора 27 i, відповідно, до входу підсилювача 19 коригування через ключ 21 надходить сигнал наступного додаткового приймача 9, чим забезпечується підтримування схемою АРП його рівня незмінним і рівним заданому, встановленому від джерела опорної напруги 17. Тож зона компенсації впливу збурень навколишнього середовища на зону вимірювання ПВПШ переміщується ближче до краю стрічки, чим забезпечується і підвищення точності вимірювань і розширення його діапазону.

Аналогічні зміщення зони компенсації впливу збурень відбуваються при подальшому відкриванні вимірювального приймача 6 в обох акустичних вузлах 2 та 3. При збільшенні ширини стрічки 1 відбувається зворотне переміщення зон компенсації збурень.

Результати експериментальних досліджень значень додаткової абсолютної похибки ПВПШ за структурою, що наведена на рис. 1, при швидкості повітряних потоків у зоні вимірювання до 2 м/с наведені на рис. 2. 


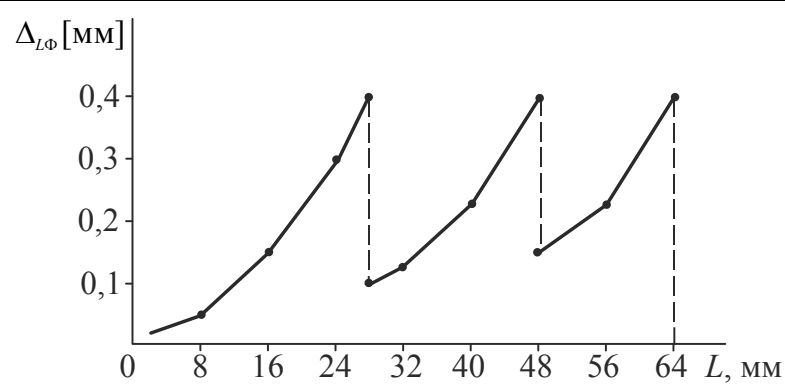

Рис. 2. Результати експериментальних досліджень значень додаткової випадкової абсолютної похибки ПВПШ при швидкості повітряних потоків (дії збурень) у зоні вимірювання до 2 м/с

Вони показують, що абсолютна випадкова складова похибки флуктуації зростає по експоненті у міру відкриття вимірювального приймача краєм контрольованої по ширині стрічки, а ії значення в межах 0,4 мм, при використанні трьох зон дискретизації може бути отримане в діапазоні вимірювання до 64 мм.

\section{Висновки}

За структурною схемою розробленого способу розширення діапазону і підвищення точності вимірювань при ультразвуковому тіньовому методі контролю ширини стрічки в повітрі досліджено пристрій, в якому в акустичній зоні вимірювання як випромінювачі і приймачі використані п'єзокерамічні перетворювачі призматичного типу ТБК-3 на резонансну частоту 109,6 кГц (розмірами у нижньої основи призми $L_{\Pi}=10$ мм та $L_{\amalg}=75(50+25)$ мм для вимірювального приймача і $L_{\amalg}=25$ мм для випромінювача при числі $m=7$ випромінювачів у пакеті). Додаткова абсолютна похибка ПВПШ від флуктуації повітряних потоків у зоні вимірювання довжиною до 64 мм складає не більше 0,4 мм при зміні швидкості потоків повітря в зоні вимірювання від 0 до $2 \mathrm{~m} / \mathrm{c}$. За відсутності розробленого способу компенсації ця похибка складала до 6 мм. Отриманий при такому способі компенсації впливу явища акустичного «федингу» коефіцієнт стабілізації дорівнює $\approx 20$. ПВПШ з розробленим способом зменшення додаткових похибок може використовуватись в умовах цеху з виробництва пакувальних стрічок.

\section{Література}

1. Рішан О.Й. Розробка структурної схеми та способу підвищення точності вимірювань ультразвукового пристрою контролю ширини стрічки у повітрі / О.Й. Рішан, А.С. Гура // Наука, технології, інновації. — УкрIНТЕI, 2017. — № 2(2). - С. $64-69$.

2. Рішан О.Й. Ультразвуковий тіньовий метод вимірювання ширини пакувальної стрічки у повітрі та дослідження параметрів вимірювальних перетворювачів для його реалізації / О.Й. Рішан, Я.В. Новачевский, В.С. Зайко // Науково-технічна інформація. 2016. —№ 2(56) - С. 78-84.

3. Ріман О.Й. Забезпечення інваріантності ультразвукового інтерферен-ційного рівнеміра на стоячій хвилі в системах нормалізації молока в ємностях / О.Й. Рішан, Ю.М. Бородкіна // Науково-технічна інформація. — 2013. — № 1(55) - С. 78-84.

4. Шандров Б.В. Технические средства автоматизации : учебник для студ. высш. учеб. заведений / Б.В. Шандров, А.Д. Чудаков. - Москва : Издательский центр «Академия», 2007. $-368 \mathrm{c}$.

5. Грінченко А.Г. Теорія автоматичного управління / Грінченко А.Г. — Харків : ХДПУ, 2000. $-272 \mathrm{c}$. 